\title{
Thyroid volumes and urinary iodine in Swiss school children, 17 years after improved prophylaxis of iodine deficiency
}

\author{
Hans Bürgi ${ }^{1}$, Luc Portmann ${ }^{2}$, Jan Podoba ${ }^{3}$, Françoise Vertongen ${ }^{4}$ and Miroslav Srbecky ${ }^{3}$ \\ ${ }^{1}$ Department of Internal Medicine, Bürgerspital, Solothurn, Switzerland, ${ }^{2}$ Department of Internal Medicine, Division of Endocrinology, CHUV, \\ Lausanne, Switzerland, ${ }^{3}$ Chair of Internal Medicine and Endocrinology, Postgraduate Medical School, Bratislava, Slovak Republic and ${ }^{4}$ Clinical \\ Chemistry Laboratory, CHU St-Pierre, Brussels, Belgium \\ (Correspondence should be addressed to H Bürgi, Medizinische Klinik, Bürgerspital, CH-45OO Solothurn, Switzerland)
}

\begin{abstract}
Salt iodine content in Switzerland was raised from 7.5 to $15 \mathrm{mg}$ per $\mathrm{kg}$ in 1980, and since then dietary iodine intake has been considered to be sufficient, even though a slight decrease due to imported food has recently been reported. The aim of this study was to establish normal values for thyroid volumes of school children who can be assumed to have had a sufficient iodine intake all their lifetime. Moreover, the present investigation was undertaken to verify that iodine sufficiency had been achieved equally in two regions each served by one of the two Swiss salt producers.

Mean iodine concentration in urine spot samples from school children was $16.1 \mu \mathrm{g} / \mathrm{dl}$, and it was identical in both the city of Lausanne $(n=215)$ and the city of Solothurn $(n=208)$. Thus it can be stated that in both cities (served by two different salt producers) iodine intake is equal and sufficient. Accordingly, thyroid volumes measured by ultrasound in school children aged 6 to 16 years were the same in both Lausanne $(n=202)$ and Solothurn $(n=207)$. Moreover, the age-adjusted median volumes at the 97th percentiles closely agree with and validate provisional international reference values recently proposed by the World Health Organisation and by the International Council for Control of Iodine Deficiency Disease.
\end{abstract}

European Journal of Endocrinology 140 104-106

\section{Introduction}

Dietary iodine supply remains marginal or frankly insufficient in many European countries, and great efforts have been invested into the mapping of iodine deficiency by measuring urinary iodine concentration as well as sonographic thyroid volume in school children by uniform standards. So far, the results of a survey in 12 European countries have been published (1). One problem which arose during this survey was the definition of normal values for thyroid volume in school children. The original normal values of Gutekunst and Martin-Teichert (2) were considered too stringent, since even in countries where the iodine supply was sufficient, such as Austria and Slovakia, 14 to $29 \%$ of school children were classified as goitrous. New (higher) reference values were therefore provisionally proposed, derived from a cluster of children from the same study whose median urinary iodine was at least $10 \mu \mathrm{g} / \mathrm{dl}(1)$.

We thought it worthwhile to validate these new reference values by performing a similar survey in Swiss children who can be assumed to have had a sufficient iodine supply during all their lifetime, using the same methods, equipment, medical personel and laboratory. Switzerland had recently been declared iodine sufficient $(3,4)$, and iodine intake in school children can be assumed to have been constant since 1980, when the salt iodine content had been raised from 7.5 to $15 \mathrm{mg}$ / $\mathrm{kg}(5-7)$. A secondary aim of the study was to compare two regions of Switzerland supplied by two different salt producers.

\section{Methods}

There are only two salt producers in Switzerland, and for the survey we chose two cities, Lausanne, supplied by Salines de Bex, and Solothurn, supplied by Vereinigte Schweizerische Rheinsalinen. The study took place in March 1997. It was approved by the institutional review boards of the two participating hospitals, and by the two local school authorities. Parents were given a written description of the study and asked for the permission that their child be examined. The examination took place in a van ('ThyroMobil') parked in the school yard. Ultrasound examination and thyroid volume calculation were performed by the same examiner (JP) and with the same equipment as in the 
Table 1 Age-specific median thyroid volumes of 6- to 16-year-old boys from the cities of Lausanne and Solothurn, compared with the reference volumes proposed by Delange et al. (1). The number of boys with thyroid volumes exceeding the 97 th percentile of the WHOICCIDD reference is also given.

\begin{tabular}{|c|c|c|c|c|c|c|c|c|c|c|c|}
\hline & \multicolumn{11}{|c|}{ Age (years) } \\
\hline & 6 & 7 & 8 & 9 & 10 & 11 & 12 & 13 & 14 & 15 & 16 \\
\hline No. of boys & 14 & 12 & 21 & 20 & 26 & 28 & 26 & 24 & 23 & 13 & 10 \\
\hline Volume (median) (ml) & 2.5 & 2.9 & 3.5 & 4.2 & 4.7 & 6.1 & 5.3 & 7.3 & 9.6 & 10.3 & 10.3 \\
\hline WHO reference (median) (ml) & 3.2 & 3.4 & 3.7 & 4.1 & 4.5 & 5.1 & 5.7 & 6.5 & 7.3 & 8.2 & - \\
\hline Boys over 97 th percentile & - & - & - & 1 & 1 & - & 1 & 1 & 3 & - & - \\
\hline
\end{tabular}

Table 2 Age-specific median thyroid volumes of 6- to 16-year-old girls from the cities of Lausanne and Solothurn, compared with the reference volumes proposed by Delange et al. (1). The number of girls with thyroid volumes exceeding the 97 th percentile of the WHOICCIDD reference is also given.

\begin{tabular}{|c|c|c|c|c|c|c|c|c|c|c|c|}
\hline & \multicolumn{11}{|c|}{ Age (years) } \\
\hline & 6 & 7 & 8 & 9 & 10 & 11 & 12 & 13 & 14 & 15 & 16 \\
\hline No. of girls & 9 & 14 & 11 & 26 & 19 & 31 & 23 & 21 & 14 & 16 & 7 \\
\hline Volume (median) (ml) & 2.5 & 3.6 & 3.8 & 3.9 & 5.3 & 5.7 & 7.7 & 9.6 & 7.7 & 9.0 & 9.1 \\
\hline WHO reference (median) (ml) & 2.9 & 3.4 & 3.9 & 4.4 & 5.0 & 5.7 & 6.3 & 7.0 & 7.7 & 8.4 & - \\
\hline Girls over 97 th percentile & - & - & - & - & 1 & - & 4 & - & - & - & - \\
\hline
\end{tabular}

previous study and urinary iodine was measured in the same laboratory, with the same statistical methods being used (1).

\section{Results}

Four children had evidence of iodine contamination with a urinary iodine level in excess of $50 \mu \mathrm{g} / \mathrm{dl}$ and they were excluded from the calculation. The mean urinary iodine in Solothurn was $16.1 \mu \mathrm{g} / \mathrm{dl}$ (median $15.1 \mu \mathrm{g} / \mathrm{dl}$, s.D. $6.3 \mu \mathrm{g} / \mathrm{dl}, n=208)$. The corresponding mean in Lausanne was $16.1 \mu \mathrm{g} / \mathrm{dl}$ (median $15.0 \mu \mathrm{g} / \mathrm{dl}$, S.D. $6.9 \mu \mathrm{g} / \mathrm{dl}, n=215)$.

Thyroid volumes from Solothurn and Lausanne were pooled as they were virtually identical, not an unexpected finding since the urinary iodine excretion was the same in both towns. Tables 1 and 2 show the thyroid volumes for boys and girls respectively, compared with the newly suggested reference volumes. As can be seen, the Swiss medians are virtually identical with some random deviations most probably due to chance. Twelve of the four hundred and eight Swiss children are above the 97th percentile of the reference population, exactly what would be expected if the reference and the Swiss population were the same.

\section{Discussion}

The urinary iodine concentrations in our schoolchildren are high and slightly above the highest reported so far in Europe by the same laboratory (1). In 1994, in the same town of Solothurn, we had found approximately 30\% lower urinary iodine values of $11.7 \mu \mathrm{g} / \mathrm{dl}$ (7). The difference could be explained by seasonal variations in milk iodine content which is 35 to $90 \mu \mathrm{g} / \mathrm{kg}$ higher in winter, when the present study was done, compared with summer, when the 1994 urine samples were collected $(8,9)$. These variations cannot, however, explain lower urinary values $(11.3 \mu \mathrm{g} / \mathrm{dl})$ which have been reported in school children from the Zurich area and the Engadine valley, since these latter urine samples were collected in the winter of 1997/1998 (10), and these differences will have to be worked out by future studies. In any event, all the school children examined in this study were born after 1980 , i.e. at least one year after the salt iodine content had been raised from 7.5 to $15 \mathrm{mg} / \mathrm{kg}$ (5). With the slight reservations discussed above we can assume that the children we have examined had a constant and sufficient iodine supply during all their lifetime. The thyroid volumes measured in this sample are virtually identical to those derived from a subsample of a European survey. Our data strongly support the recommendation by the World Health Organisation (WHO) and the International Council for Control of Iodine Deficiency Disorders (ICCIDD) to use the European values as the international standard reference in future sonographic surveys (11)

It is reassuring to see that two Swiss regions served by two different salt producers have exactly the same urinary iodine excretion, attesting to the quality of salt delivered by the only two salt producers in Switzerland. It must be conceded, though, that recent investigations have suggested a decreasing iodine supply in adults, although the values were not alarming (12-14). In any 
event, it can be expected that the tendency of a decreased iodine supply, attributed to the importation of food prepared with non-iodized salt, will soon be reversed, because as of mid-1998 the salt iodine content will be increased from 15 to $20 \mathrm{mg} / \mathrm{kg}$.

In summary, our survey documents a sufficient iodine supply in school children living in two different Swiss cities, served by two different salt manufacturers. Accordingly, thyroid volumes are virtually superimposable with the reference values recently proposed by WHO and ICCIDD.

\section{Acknowledgements}

We are very grateful to Merck KGaA Darmstadt (Dr W Ott) and to E Merck Switzerland AG (Mr B-D Westphal) for putting at our disposal the ThyroMobil van and for the logistic and financial support. We also thank the authorities of the two schools involved for their excellent collaboration in this study.

\section{References}

1 Delange F, Benker G, Caron Ph, Eber O, Ott W, Peter F et al. Thyroid volume and urinary iodine in European school children: standardization of values for assessment of iodine deficiency. European Journal of Endocrinology 1997136 180-187.

2 Gutekunst R \& Martin-Teichert H. Requirements for goiter surveys and the determination of thyroid size. In Iodine Deficiency in Europe. A Continuing Concern, pp 109-118. Eds F Delange, JT Dunn \& D Glinoer. New York: Plenum Press, 1993.

3 Gutekunst R \& Scriba PC. Goiter and iodine deficiency in Europe. The European Thyroid Association report as updated in 1988. Journal of Endocrinological Investigation 198912 209-220.

4 Delange F, Dunn JT \& Glinoer D (Eds). Iodine Deficiency in Europe: A Continuing Concern. New York: Plenum Press, 1993.
5 Bürgi H, Supersaxo Z \& Selz B. Iodine deficiency diseases in Switzerland one hundred years after Theodor Kocher's survey: a historical review with some new goitre prevalence data. Acta Endocrinologica 1990123 577-590.

6 Bürgi H, Supersaxo Z \& Dürig P. Status of iodine nutrition in Switzerland. In Iodine Deficiency in Europe. A Continuing Concern, pp 367-371. Eds F Delange, JT Dunn \& D Glinoer. New York: Plenum Press, 1993.

7 Truong TH, Gerber H, Haenel A \& Bürgi H. Jodversorgung in verschiedenen Lebensphasen und sonographische Schilddrüsenvolumina bei Schulkindern in einer Gegend der Schweiz. Schweizerische Medizinische Wochenschrift 1997127 715-721.

8 Bürgi H, Baumgartner $\mathrm{H}$ \& Steiger G. Gibt es eine obere Verträglichkeitsgrenze der alimentären Jodzufuhr? Schweizerische Medizinische Wochenschrift 1982112 2-7.

9 Schällibaum M. Saisonale und regionale Schwankungen der Jodkonzentrationen in Lieferantenmilchproben. Schweizerische Vereinigung Zuchthygiene, Buiatrik, Information Mai 19911035.

10 Zimmermann MB, Hess S, Zeder C \& Hurrell RF. Urinary iodine concentrations in Swiss school children from the Zurich area and the Engadine valley. Schweizerische Medizinische Wochenschrift $1998128770-774$.

11 Delange F. Recommended normative values for thyroid volume in children aged 6-15 years. Bulletin of the World Health Organisation 199775 95-97.

12 Als C, Lauber K, Brander L, Lüscher D \& Rösler H. The instability of dietary iodine supply over time in an affluent society. Experientia $199551623-633$.

13 Solca B \& Gerber H. Jodversorgung in verschiedenen Regionen der Schweiz: Ein Vergleich zwischen Stadt und Land in den Kantonen Bern und Tessin. Schweizerische Medizinische Wochenschrift 1996 126 (Suppl 74/I) 11S

14 Mokhtech I, Lemarchand Th, Hohlfeld P \& Portmann L. Evidence d'un apport iodé insuffisant pendant la grossesse et le portpartum dans le canton de Vaud. Schweizerische Medizinische Wochenschrift 1995125 (Suppl 69) 57S.

Received 4 September 1998

Accepted 28 September 1998 